\title{
Intra- and Intergeneric Similarities of Chromobacterium and Janthinobacterium Ribosomal Ribonucleic Acid Cistrons
}

\author{
J. DE LEY, P. SEGERS, AND M. GILLIS \\ Laboratory of Microbiology and Microbial Genetics, State University, Ledeganckstraat 35, \\ B-9000 Gent, Belgium
}

\begin{abstract}
We prepared hybrids between ${ }^{14} \mathrm{C}$-labeled ribosomal ribonucleic acid (rRNA) from either Chromobacterium violaceum NCTC 9757 or Chromobacterium lividum NCTC 9796 and deoxyribonucleic acid (DNA) from a great variety of named gram-negative bacteria, including many type and reference strains. Each hybrid was described by two parameters: (i) $T_{m(e)}$, the temperature at which $50 \%$ of the hybrid was denatured; (ii) the percent rRNA binding, the amount (micrograms) of $\left[{ }^{14} \mathrm{C}\right] \mathrm{rRNA}$ duplexed in stringent conditions per $100 \mu \mathrm{g}$ of filter-fixed homologous or heterologous DNA. Each taxon occupied a definite area on the rRNA similarity maps. All $C$. lividum and $C$. violaceum strains formed tight separate clusters around their neotype strains. The rRNA parameters of both taxa were about as different from each other as was the case for many genera. Both taxa are phenotypically and genotypically (by DNA-DNA hybridization) likewise very different. We proposed to elevate each cluster to genus rank as $C$. violaceum and Janthinobacterium lividum. The following strains were misnamed and belonged in neither genus: " $C$. lividum" = "C." folium NCTC 10590 and 10591; " C. lividum" GA; "C." marismortui ATCC 17056; "Pseudomonas" ("Chromobacterium") iodinum ATCC 9897, 15728, and 15729; "C." indicum-rubrum (now Serratia marcescens) NCTC 2847; and "C." viscosum (now Corynebacterium sp.) NCTC 2416. The rRNA cistrons of Chromobacterium and Janthinobacterium resembled most closely those of Pseudomonas section II and III, the authentic Alcaligenes, Bordetella bronchiseptica, the $\mathrm{H}_{2}$-oxidizing Alcaligenes eutrophus and Alcaligenes paradoxus, and Comamonas percolans NCIB 8193. These taxa displayed a number of phenotypical similarities. We suggested that all these taxa are the closest taxonomic relatives of Chromobacterium and Janthinobacterium.
\end{abstract}

In a previous paper (16) one of us reported that the quantitative comparison of ribosomal ribonucleic acid (rRNA) cistron similarities is a powerful and quick tool to detect the degree of intergeneric relationships between remotely related taxa, when other methods frequently fail (e.g., deoxyribonucleic acid [DNA]-DNA hybridization) or are very time consuming (e.g., numerical analysis of phenotypic features). There seemed to be a distinct correlation between the thermal stability of heterologous DNA-rRNA hybrids and the overall phenotypic similarities of the organisms concerned. These findings were discovered and explored with the Rhizobiaceae (16).

In the present paper we shall describe the rRNA similarities of Chromobacterium, both within the genus and with other genera. Chromobacterium is a particularly interesting genus for several reasons. (i) Its internal classification is very well known from the numerical analysis of its phenotypical features (29-32). Two taxa were proposed, C. violaceum and C. lividum. (ii) Sneath (32) pointed out that this genus is not a very natural taxon, since both species are almost as different from each other as are many genera (iii) The exact taxonomic position and affiliation of Chromobacterium is unknown. In Bergey's Manual, 7th ed. (4), it was grouped together with Agrobacterium and Rhizobium in the Rhizobiaceae. This was not justified (20), and Chromobacterium is now temporarily listed in Bergey's Manual, 8th ed. (32), as a genus of uncertain affiliation in an appendix to the Enterobacteriaceae and Vibrionaceae, a position that is likewise totally unjustified because of considerable differences in phenotypical features and DNA base composition (guanine-plus-cytosine $[\mathrm{G}+\mathrm{C}]$ content). As a conclusion of part of our data we propose in the Discussion a new genus name Janthinobacterium for the strains of the C. lividum taxon. For the sake of clarity we shall use this genus name from now on instead of $C$. lividum. The nomenclature of $C$. violaceum will be maintained.

\section{MATERIALS AND METHODS}

Bacterial strains and growth media. The strains used are listed in Table 1. The bacteriological purity was checked by plating and by examination of living 
TABLE 1. List of organisms used ${ }^{a}$

\begin{tabular}{|c|c|c|c|c|c|c|c|c|}
\hline \multirow{4}{*}{$\begin{array}{c}\text { Se- } \\
\text { quence } \\
\text { no. } \\
\text { in } \\
\text { Fig. } 3 \\
\text { or } 4\end{array}$} & \multirow{4}{*}{$\begin{array}{l}\text { Organism used for } \\
\text { DNA prepn }\end{array}$} & \multirow{4}{*}{$\begin{array}{l}\text { Origin } \\
\text { and } \\
\text { strain no. }\end{array}$} & \multirow{4}{*}{$\begin{array}{l}\text { Mol\% } \\
\text { G+C }\end{array}$} & \multirow{4}{*}{$\begin{array}{l}\text { Strain } \\
\text { status }\end{array}$} & \multicolumn{4}{|c|}{$\begin{array}{l}\text { Hybridization with } \\
{\left[{ }^{14} \mathrm{C}\right] \mathrm{rRNA} \text { from: }}\end{array}$} \\
\hline & & & & & \multicolumn{2}{|c|}{$\begin{array}{c}J . \\
\text { lividum } \\
\text { NCTC } 9796\end{array}$} & \multicolumn{2}{|c|}{$\begin{array}{c}C . \\
\text { violaceum } \\
\text { NCTC } 9757\end{array}$} \\
\hline & & & & & & rRNA & & $\mathrm{rRNA}$ \\
\hline & & & & & $T_{n t(e)}$ & bind- & $T_{m(e)}$ & bind- \\
\hline & $\begin{array}{l}\text { Proposed genus Chromobac- } \\
\text { terium emend. }\end{array}$ & & & & & & & \\
\hline 1 & C. violaceum & NCTC 9757 & 67.2 & Neotype (5) & 67.5 & 0.17 & 80.0 & 0.27 \\
\hline 2 & C. violaceum & NCTC 8683 & 65.2 & & 69.5 & 0.18 & 76.5 & 0.28 \\
\hline 3 & C. violaceum & NCTC 8684 & 66.7 & & 70.5 & 0.18 & 78.0 & 0.27 \\
\hline 4 & C. violaceum & NCTC 8685 & 66.3 & & 69.0 & 0.14 & 77.5 & 0.26 \\
\hline 5 & C. violaceum & NCTC 9370 & 66.4 & & 71.0 & 0.20 & 76.5 & 0.25 \\
\hline 6 & C. violaceum & NCTC 9371 & 66.1 & & 70.0 & 0.16 & 76.5 & 0.29 \\
\hline 7 & C. violaceum & NCTC 9372 & 66.2 & & 70.0 & 0.18 & 78.0 & 0.26 \\
\hline 8 & C. violaceum & NCTC 9373 & 65.8 & & 68.5 & 0.15 & 78.0 & 0.25 \\
\hline 9 & C. violaceum & NCTC 9374 & 65.9 & & 70.0 & 0.17 & 80.0 & 0.26 \\
\hline 10 & C. violaceum & NCTC 9377 & 66.9 & & 70.0 & 0.17 & 78.5 & 0.27 \\
\hline 11 & C. violaceum & NCTC 9695 & 65.2 & & 68.0 & 0.17 & 76.5 & 0.29 \\
\hline \multirow[t]{2}{*}{12} & C. violaceum & NCTC 9696 & 66.5 & & 67.0 & 0.18 & 80.0 & 0.29 \\
\hline & $\begin{array}{l}\text { Proposed genus Janthinobac- } \\
\text { terium }\end{array}$ & & & & & & & \\
\hline 13 & J. lividum & NCTC 9796 & 65.5 & $\begin{array}{l}\text { Neotype (this pa- } \\
\text { per) }\end{array}$ & 78.5 & 0.21 & 66.5 & 0.19 \\
\hline 14 & J. lividum & DA (Sneath) & 66.1 & & 79.0 & 0.21 & 67.5 & 0.18 \\
\hline 15 & J. lividum & MB (Sneath) & 66.1 & & 79.0 & 0.18 & 68.5 & 0.19 \\
\hline 16 & J. lividum & NCTC 8661 & 65.4 & & 79.0 & 0.22 & 69.0 & 0.17 \\
\hline 17 & J. lividum & HA (Sneath) & 64.5 & & 77.5 & 0.23 & 68.0 & 0.175 \\
\hline 18 & J. lividum & P1 & & & 77.0 & 0.225 & 67.5 & 0.16 \\
\hline 19 & J. lividum & ATCC 14487 & 61.2 & & 78.0 & 0.23 & 69.0 & 0.16 \\
\hline 20 & J. lividum & RU (Sneath) & 65.5 & & 77.5 & 0.19 & 68.5 & 0.15 \\
\hline 21 & J. lividum & NCTC 7150 & 65.5 & & 77.5 & 0.18 & 68.0 & 0.17 \\
\hline 22 & J. lividum & HD (Sneath) & 66.0 & & 78.5 & 0.21 & 68.0 & 0.16 \\
\hline \multirow[t]{2}{*}{23} & J. amethystinum & ATCC 6915 & 65.1 & & 78.0 & 0.23 & 68.0 & 0.16 \\
\hline & Misnamed chromobacteria & & & & & & & \\
\hline 24 & "C. lividum"(= "C. folium") & NCTC 10590 & 61.1 & & 59.0 & 0.02 & 57.5 & 0.05 \\
\hline 25 & "C. lividum" (= "C. folium") & NCTC 10591 & 63.0 & & 61.0 & 0.03 & 58.0 & 0.04 \\
\hline 26 & "C. lividum" & GA (Sneath) & 71.4 & & 69.5 & 0.03 & 66.5 & 0.045 \\
\hline \multirow[t]{2}{*}{27} & "C." marismortui & ATCC 17056 & 61.8 & Holotype (33) & 61.5 & 0.12 & 61.5 & 0.15 \\
\hline & Other genera & & & & & & & \\
\hline 28 & Pseudomonas acidovorans & ATCC 15668 & 66.5 & Type (5) & 71.0 & 0.09 & 66.5 & 0.08 \\
\hline 29 & P. acidovorans & ATCC 17476 & 65.0 & & 70.5 & 0.09 & & \\
\hline 30 & P. delafieldii & ATCC $17506 t_{2}$ & 64.3 & & 74.0 & 0.11 & 70.0 & 0.12 \\
\hline 31 & P. desmolytica & ATCC 15005 & 66.6 & & 71.0 & 0.08 & & \\
\hline 32 & P. testosteroni & NCTC 10698 & 62.5 & Type (5) & 70.5 & 0.19 & 67.0 & 0.18 \\
\hline 33 & P. testosteroni & ATCC $17510 t_{2}$ & 63.0 & & 70.5 & 0.16 & 67.5 & 0.15 \\
\hline 34 & P. testosteroni & ATCC 17407 & 64.5 & & 70.5 & 0.20 & 66.5 & 0.17 \\
\hline 35 & P. testosteroni & ATCC 17409 & 63.0 & & 70.5 & 0.16 & 66.5 & 0.15 \\
\hline 36 & P. testosteroni & ATCC 11996 & 62.5 & & 71.5 & 0.18 & & \\
\hline 37 & P. palleronii & ATCC $17724 t_{I}$ & 65.9 & Type (5) & 72.0 & 0.07 & 67.5 & 0.05 \\
\hline 38 & $P$. facilis & ATCC 11228 & 64.7 & Type (5) & 73.0 & 0.09 & & \\
\hline 39 & P. facilis & ATCC 15376 & 63.7 & & 70.0 & 0.09 & 66.0 & 0.09 \\
\hline 40 & P. facilis & ATCC $17695 t_{1}$ & 65.2 & & 72.5 & 0.10 & 68.0 & 0.10 \\
\hline 41 & P. facilis & ATCC $17695 \mathrm{t}_{2}$ & 65.7 & & 71.5 & 0.09 & & \\
\hline 42 & P. solanacearum & NCPPB 325 & 66.1 & $\begin{array}{l}\text { Proposed neotype } \\
\text { (5) }\end{array}$ & 71.0 & 0.07 & 71.0 & 0.08 \\
\hline 43 & $P$. solanacearum & NCPPB 282 & 67.4 & & 70.0 & 0.06 & 71.0 & 0.07 \\
\hline 44 & P. solanacearum & NCPPB 1019 & 68.0 & & & & 70.0 & 0.09 \\
\hline 45 & P. solanacearum & NCPPB 613 & 68.1 & & 68.5 & 0.07 & 70.5 & 0.07 \\
\hline 46 & P. solanacearum & NCPPB 253 & & & & & 70.0 & 0.09 \\
\hline 47 & P. cepacia & NCTC 10661 & 67.4 & $\begin{array}{l}\text { Proposed holotype } \\
\text { (34) for P. mul- } \\
\text { tivorans }\end{array}$ & 72.0 & 0.09 & 70.5 & 0.10 \\
\hline 48 & P. cepacia & ATCC 25416 & 67.5 & Type (5) & 71.5 & 0.10 & 70.5 & 0.09 \\
\hline 49 & P. marginata & ATCC 10248 & 68.6 & Type (5) & & & 70.5 & 0.07 \\
\hline 50 & P. ruhlandii & ATCC 15749 & 64.9 & Type (5) & 70.0 & 0.06 & 70.0 & 0.06 \\
\hline 51 & P. fluorescens & ATCC 13525 & 60.2 & Neotype (5) & 63.5 & 0.11 & 61 & 0.13 \\
\hline
\end{tabular}


TABLE 1-Continued

\begin{tabular}{|c|c|c|c|c|c|c|c|c|}
\hline \multirow{3}{*}{$\begin{array}{l}\text { Se- } \\
\text { quence } \\
\text { no. } \\
\text { in } \\
\text { Fig. } 3 \\
\text { or } 4\end{array}$} & \multirow{3}{*}{$\begin{array}{l}\text { Organism used for } \\
\text { DNA prepn }\end{array}$} & \multirow{3}{*}{$\begin{array}{l}\text { Origin } \\
\text { and } \\
\text { strain no. }\end{array}$} & \multirow{3}{*}{$\begin{array}{l}\mathrm{Mol} \% \\
\mathrm{G}+\mathrm{C}\end{array}$} & \multirow{3}{*}{$\begin{array}{l}\text { Strain } \\
\text { status }\end{array}$} & \multicolumn{4}{|c|}{$\begin{array}{l}\text { Hybridization with } \\
{\left[{ }^{14} \mathrm{C}\right] \mathrm{rRNA} \text { from: }}\end{array}$} \\
\hline & & & & & \multicolumn{2}{|c|}{$\begin{array}{c}J . \\
\text { lividum } \\
\text { NCTC } 9796\end{array}$} & \multicolumn{2}{|c|}{$\begin{array}{c}C . \\
\text { violaceum } \\
\text { NCTC } 9757\end{array}$} \\
\hline & & & & & $\begin{array}{l}T_{m(e)} \\
\left({ }^{\circ} \mathrm{C}\right)\end{array}$ & $\begin{array}{c}\text { rRNA } \\
\text { bind- } \\
\text { ing } \\
(\%)\end{array}$ & $\begin{array}{l}T_{m(e)} \\
\left({ }^{\circ} \mathrm{C}\right)\end{array}$ & $\begin{array}{c}\text { rRNA } \\
\text { bind- } \\
\text { ing } \\
(\%)\end{array}$ \\
\hline 52 & P. aeruginosa & ATCC 7700 & 66.8 & & 62.5 & 0.08 & & \\
\hline 53 & $P$. aeruginosa & CCEB 481 & 66.8 & Neotype (5) & 62.5 & 0.07 & & \\
\hline 54 & P. putida & ATCC 23467 & 63.4 & Representative (5) & 62.0 & 0.09 & & \\
\hline 55 & P. cichorii & NCPPB 1512 & 60.3 & & 62.5 & 0.10 & & \\
\hline 56 & P. stutzeri & ATCC 17588 & 64.7 & $\begin{array}{l}\text { Suggested neotype } \\
\text { (5) }\end{array}$ & 64.5 & 0.10 & & \\
\hline 57 & P. oleovorans & NCTC 10692 & & Cotype (33) & 63.0 & 0.09 & & \\
\hline 58 & P. maltophilia & ATCC 13637 & 65.0 & Type (5) & 62.5 & 0.09 & & \\
\hline 59 & P. mucidolens & NCTC 8068 & 61.0 & Cotype (33) & 62.5 & 0.09 & & \\
\hline 60 & $P$. rubescens & NCTC 10695 & 45.9 & Cotype (33) & 61.0 & 0.10 & & \\
\hline 61 & "P." atlantica & CCEB 506 & 66.5 & Holotype (33) & 60.0 & 0.05 & & \\
\hline 62 & “P." diminuta & CCEB 513 & 67.3 & Type (5) & 60.0 & 0.04 & & \\
\hline 63 & "P." iodinum & ATCC 9897 & 63.2 & Holotype (33) & 55.5 & 0.05 & 53.0 & 0.06 \\
\hline 64 & "P." iodinum & ATCC 15728 & 62.0 & & 57.0 & 0.06 & 53.5 & 0.06 \\
\hline 65 & "P." iodinum & ATCC 15729 & 61.8 & & & & 51.5 & 0.04 \\
\hline 66 & Comamonas percolans & NCIB 8193 & 64.3 & $\begin{array}{l}\text { Proposed paratype } \\
\text { (33) for Vibrio }\end{array}$ & 66.0 & 0.18 & 68.5 & 0.18 \\
\hline & & & & percolans & & & & \\
\hline 67 & Bordetella bronchiseptica & ATCC 10580 & 68.2 & & 69.0 & 0.08 & 69.5 & 0.09 \\
\hline 68 & B. bronchiseptica & NCTC 8761 & 69.5 & & 69.0 & 0.07 & 69.5 & 0.08 \\
\hline 69 & B. bronchiseptica & NCTC 452 & 68.9 & Type (5) & 68.5 & 0.07 & 67.0 & 0.08 \\
\hline 70 & $\begin{array}{l}\text { Achromobacter denitrifi- } \\
\text { cans }\end{array}$ & $\mathrm{M} 250$ & 67.7 & & 71.0 & 0.06 & 68.0 & 0.07 \\
\hline 71 & Ach. xylosoxidans & KM 583 & 69.5 & & 70.0 & 0.08 & 67.0 & 0.06 \\
\hline 72 & Alcaligenes faecalis & AB 1286 & 57.2 & & 70.0 & 0.09 & & \\
\hline 73 & Alc. faecalis & ATCC 8750 & 57.3 & Reference (5) & 69.5 & 0.09 & 66.5 & 0.10 \\
\hline 74 & Alc. odorans & GIL 117 & 57.9 & & 70.0 & 0.10 & 67.5 & 0.08 \\
\hline 75 & Alc. eutrophus & ATCC 17697 & 67.2 & Type (5) & 71.5 & 0.09 & 67.5 & 0.08 \\
\hline 76 & Alc. eutrophus & ATCC 17698 & 66.9 & & 72.0 & 0.09 & & \\
\hline 77 & Alc. paradoxus & ATCC $17713 t_{1}$ & 67.7 & Type (5) & 68.5 & 0.04 & & \\
\hline 78 & Alc. paradoxus & ATCC 17712 & 67.9 & & 69.0 & 0.05 & & \\
\hline 79 & Alc. paradoxus & ATCC $17549 t_{1}$ & 67.1 & & 70.5 & 0.04 & 67.0 & 0.03 \\
\hline 80 & Alc. paradoxus & ATCC $17549 t_{2}$ & 67.9 & & 68.0 & 0.04 & & \\
\hline 81 & Alc. paradoxus & ATCC $17719 t_{2}$ & 66.9 & & 69.5 & 0.04 & 67.0 & 0.04 \\
\hline 82 & Alc. pacificus & ATCC 27122 & 66.7 & $\begin{array}{l}\text { Type ATCC (1974 } \\
\text { Catalog) }\end{array}$ & 60.5 & 0.10 & & \\
\hline 83 & Alc. venustus & ATCC 27125 & 53.2 & $\begin{array}{l}\text { Type ATCC (1974 } \\
\text { Catalog) }\end{array}$ & 62.0 & 0.09 & & \\
\hline 84 & Alc. aestus & ATCC 27128 & 57.4 & $\begin{array}{l}\text { Type ATCC (1974 } \\
\text { Catalog) }\end{array}$ & 62.5 & 0.14 & & \\
\hline 85 & Alc. aquamarinus & NCMB 557 & 57.9 & Reference (5) & 62.5 & 0.125 & & \\
\hline 86 & Azotobacter vinelandii & NCIB 8660 & 65.0 & & 62.0 & 0.12 & & \\
\hline 87 & Azo.paspali & $22 \mathbf{B}$ & 63.7 & & 61.0 & 0.10 & & \\
\hline 88 & Azomonas agilis & SS4 & 52.8 & & 62.0 & 0.06 & & \\
\hline 89 & Derxia gummosa & $\mathrm{D}$ & & & & & 68.0 & 0.13 \\
\hline 90 & Derxia sp. & D12 & 72.6 & & 71.0 & 0.09 & & \\
\hline 91 & Xanthomonas campestris & ICPB T11 & 64.3 & $\begin{array}{l}\text { Cotype for } X . t a r \\
\quad \text { axaci }(33)\end{array}$ & 64.0 & 0.04 & 60.0 & 0.07 \\
\hline 92 & $X$. campestris & ICPB V136 & 66.4 & & 62.5 & 0.04 & & \\
\hline 93 & $X$. campestris & ICPB P121 & 66.5 & & 62.5 & 0.05 & 61.5 & 0.06 \\
\hline 94 & $X$. fragariae & NCPPB 1822 & 63.3 & & 65.0 & 0.07 & 61.5 & 0.06 \\
\hline 95 & $X$. albilineans & NCPPB 2503 & 64.5 & & 63.0 & 0.07 & 59.5 & 0.04 \\
\hline 96 & $X$. axonopodis & NCPPB 457 & 65.0 & Cotype (33) & 64.5 & 0.04 & & \\
\hline 97 & Aplanobacter populi & Bt3 & 65.0 & & 64.0 & 0.05 & 61.0 & 0.06 \\
\hline 98 & Apl. populi & Spm 11 & 65.2 & & 63.0 & 0.05 & 60.0 & 0.06 \\
\hline 99 & Spirillum sinuosum & NCIB 9010 & 59.0 & Type (5) & & & 68.0 & 0.14 \\
\hline 100 & S. polymorphum & NCIB 9072 & 63.7 & Type (5) & 60.0 & 0.07 & & \\
\hline 101 & $\begin{array}{l}\text { Rhodopseudomonas gelati- } \\
\text { nosa }\end{array}$ & NCIB 8290 & 70.1 & Neotype (5) & & & 67.5 & 0.06 \\
\hline 102 & $R$. palustris & NCIB 8252 & 67.2 & Neotype (5) & 59.5 & 0.03 & & \\
\hline 103 & R. sphaeroides & NCIB 8253 & 68.4 & Type (5) & 58.5 & 0.05 & & \\
\hline
\end{tabular}


TABLE 1-Continued

\begin{tabular}{|c|c|c|c|c|c|c|c|c|}
\hline \multirow{3}{*}{$\begin{array}{l}\text { Se- } \\
\text { quence } \\
\text { no. } \\
\text { in } \\
\text { Fig. } 3 \\
\text { or } 4\end{array}$} & \multirow{3}{*}{$\begin{array}{l}\text { Organism used for } \\
\text { DNA prepn }\end{array}$} & \multirow{3}{*}{$\begin{array}{l}\text { Origin } \\
\text { and } \\
\text { strain no. }\end{array}$} & \multirow{3}{*}{$\begin{array}{c}\mathrm{Mol} \% \\
\mathrm{G}+\mathrm{C}\end{array}$} & \multirow{3}{*}{$\begin{array}{l}\text { Strain } \\
\text { status }\end{array}$} & \multicolumn{4}{|c|}{$\begin{array}{l}\text { Hybridization with } \\
{\left[{ }^{14} \text { C]rRNA from: }\right.}\end{array}$} \\
\hline & & & & & \multicolumn{2}{|c|}{$\begin{array}{c}J . \\
\text { lividum } \\
\text { NCTC } 9796\end{array}$} & \multicolumn{2}{|c|}{$\begin{array}{c}C . \\
\text { violaceum } \\
\text { NCTC } 9757\end{array}$} \\
\hline & & & & & $\begin{array}{l}T_{m(e)} \\
\left({ }^{\circ} \mathrm{C}\right)\end{array}$ & $\begin{array}{c}\text { rRNA } \\
\text { bind- } \\
\text { ing } \\
(\%)\end{array}$ & $\begin{array}{l}T_{m(e)} \\
\left({ }^{\circ} \mathrm{C}\right)\end{array}$ & $\begin{array}{l}\text { rRNA } \\
\text { bind- } \\
\text { ing } \\
(\%)\end{array}$ \\
\hline 104 & Escherichia coli & B & 52.2 & & 62.0 & 0.10 & 60.0 & 0.14 \\
\hline 105 & Salmonella typhimurium & 1 & 55.2 & & 61.5 & 0.13 & 63.0 & 0.14 \\
\hline 106 & Enterobacter aerogenes & NCTC 10006 & 53.8 & Type (5) & & & 60.0 & 0.15 \\
\hline 107 & Ent. agglomerans & IPO 445 & 60.6 & & 62.0 & 0.13 & 61.5 & 0.18 \\
\hline 108 & Edwardsiella tarda & NCTC 10396 & 56.7 & Type (5) & 61.5 & 0.18 & & \\
\hline 109 & Klebsiella aerogenes & NCTC 8172 & 55.9 & $\begin{array}{cr}\text { Proposed neotype } \\
\text { ATCC }\end{array}$ & 63.0 & 0.14 & & \\
\hline & & & & Catalog) & & & & \\
\hline 110 & K. rubiacearum & & 59.6 & & 64.0 & 0.15 & 60.5 & 0.14 \\
\hline 111 & Hafnia protea & 540 & 49.3 & & 63.0 & 0.11 & & \\
\hline 112 & Proteus morganii & NCTC 2815 & 52.3 & & 63.5 & 0.14 & 63.0 & 0.16 \\
\hline 113 & Serratia marcescens & ATCC 10759 & 59.2 & $\begin{array}{l}\text { Suggested working } \\
\text { strain (33) }\end{array}$ & 64.0 & 0.12 & & \\
\hline 114 & S. marcescens & CCEB 293 & 59.9 & & 62.5 & 0.09 & & \\
\hline 115 & $\begin{array}{l}\text { S. marcescens (Chromobac- } \\
\text { terium indicum-rubrum) }\end{array}$ & NCTC 2847 & 55.3 & & 63.5 & 0.10 & 62.5 & 0.13 \\
\hline 116 & Yersinia rodentium & NCTC 1102 & 48.9 & & 64.0 & 0.13 & 61.5 & 0.14 \\
\hline 117 & Vibrio albensis & NCMB 41 & 47.8 & $\begin{array}{l}\text { Proposed reference } \\
\text { (5) }\end{array}$ & 60.5 & 0.14 & & \\
\hline 118 & V. fischeri & NCMB 1281 & 40.9 & Neotype (5) & 61.0 & 0.14 & & \\
\hline 119 & V. marinus & NCMB 1143 & 42.3 & & 61.0 & 0.18 & & \\
\hline 120 & $V$. marinus & ATCC 15382 & 43 & & 61.5 & 0.14 & & \\
\hline 121 & V. parahaemolyticus & Sak 3 & 47.6 & & 61.0 & 0.17 & & \\
\hline 122 & V. parahaemolyticus & FC 1011 & 47.9 & & 62.5 & 0.16 & & \\
\hline 123 & V. alginolyticus & ATCC 17749 & 45.5 & $\begin{array}{l}\text { Suggested working } \\
\text { strain for Vibrio } \\
\text { parahaemolyti- } \\
\text { cus (5) }\end{array}$ & 64.0 & 0.18 & & \\
\hline 124 & V. anguillarum & ATCC 19264 & 44.9 & $\begin{array}{l}\text { Suggested working } \\
\text { strain (5) }\end{array}$ & 62.0 & 0.13 & & \\
\hline 125 & V. non-cholera & E 509 & 49.0 & & 62.5 & 0.17 & 63.0 & 0.23 \\
\hline 126 & Beneckea natriegens & ATCC 14048 & 44.9 & $\begin{array}{l}\text { Type ATCC (1974 } \\
\text { Catalog) }\end{array}$ & 62.0 & 0.12 & & \\
\hline 127 & B. nigrapulchrituda & ATCC 27043 & 46.1 & $\begin{array}{l}\text { Type ATCC (1974 } \\
\text { Catalog) }\end{array}$ & 62.5 & 0.09 & & \\
\hline 128 & Lucibacterium harveyi & NCMB 1280 & 45.5 & Type (5) & 61.5 & 0.15 & 61.5 & 0.17 \\
\hline 129 & L. harveyi & NCMB 1 & 45.0 & & 62.0 & 0.15 & & \\
\hline 130 & L. harveyi & NCMB 24 & 46.5 & & 62.0 & 0.14 & & \\
\hline 131 & $\begin{array}{l}\text { Photobacterium phospho- } \\
\text { reum }\end{array}$ & NCMB 844 & 40.5 & $\begin{array}{l}\text { Suggested working } \\
\text { type strain }(5)\end{array}$ & 62.0 & 0.22 & 61.5 & 0.26 \\
\hline 132 & Ph. mandapamensis & NCMB 1198 & 41.8 & $\begin{array}{l}\text { Suggested working } \\
\text { type strain (5) }\end{array}$ & 63.0 & 0.22 & 62.0 & 0.27 \\
\hline 133 & Ph. mandapamensis & NCMB 391 & 40.7 & $\begin{array}{l}\text { Suggsted working } \\
\text { type strain (5) }\end{array}$ & 63.0 & 0.21 & 62.0 & 0.24 \\
\hline 134 & Plesiomonas shigelloides & NCTC 10360 & 52.0 & Holotype (33) & 63.0 & 0.20 & 61.0 & 0.28 \\
\hline 135 & $\begin{array}{l}\text { Aeromonas punctata subsp. } \\
\text { caviae }\end{array}$ & NCIB 9232 & 59.1 & & 61.5 & 0.16 & 62.0 & 0.20 \\
\hline 136 & Aer. hydrophila & AB 833 & 59.5 & & 60.5 & 0.16 & 63.0 & 0.22 \\
\hline 137 & $\begin{array}{l}\text { Aer. hydrophila subsp. hy- } \\
\quad \text { drophila }\end{array}$ & NCIB 9233 & 58.9 & & 63.0 & 0.19 & & \\
\hline 138 & Aer. salmonicida & NCMB 833 & 57.0 & $\begin{array}{l}\text { Suggested neotype } \\
(33)\end{array}$ & 62.0 & 0.18 & & \\
\hline 139 & Agarbacterium alginicum & NCMB 886 & 53.2 & & 63.0 & 0.13 & 63.5 & 0.12 \\
\hline 140 & Cellvibrio vulgaris & NCIB 8633 & 51.5 & Cotype (33) & 62.0 & 0.06 & & \\
\hline 141 & C. vulgaris & NCIB 8975 & 48.1 & & & & 61.5 & 0.07 \\
\hline 142 & $\begin{array}{l}\text { Acetobacter aceti subsp. } \\
\text { aceti }\end{array}$ & NCIB $8621 t_{1}$ & 57.9 & $\begin{array}{l}\text { Suggested neotype } \\
\text { (5) }\end{array}$ & & & 60.0 & 0.06 \\
\hline 143 & Ace. aceti subsp. aceti & NCIB 8554 & 56.9 & & 60.5 & 0.07 & & \\
\hline 144 & Ace. acet $i$ subsp. xylinum & NCIB 8246 & 60.7 & & 59.5 & 0.08 & & \\
\hline 145 & $\begin{array}{l}\text { Ace. pasteurianus subsp. } \\
\text { pasteurianus }\end{array}$ & $23 \mathrm{kl}+$ & 55.5 & & 58.5 & 0.11 & & \\
\hline
\end{tabular}


TABLE 1-Continued

\begin{tabular}{|c|c|c|c|c|c|c|c|c|}
\hline \multirow{3}{*}{$\begin{array}{l}\text { Se- } \\
\text { quence } \\
\text { no. } \\
\text { in } \\
\text { Fig. } 3 \\
\text { or } 4\end{array}$} & \multirow{3}{*}{$\begin{array}{l}\text { Organism used for } \\
\text { DNA prepn }\end{array}$} & \multirow{3}{*}{$\begin{array}{l}\text { Origin } \\
\text { and } \\
\text { strain no. }\end{array}$} & \multirow{3}{*}{$\begin{array}{l}\mathrm{Mol} \% \\
\mathrm{G}+\mathrm{C}\end{array}$} & \multirow{3}{*}{$\begin{array}{l}\text { Strain } \\
\text { status }\end{array}$} & \multicolumn{4}{|c|}{$\begin{array}{l}\text { Hybridization with } \\
{\left[{ }^{14} \mathrm{C}\right] \mathrm{rRNA} \text { from: }}\end{array}$} \\
\hline & & & & & \multicolumn{2}{|c|}{$\begin{array}{c}J . \\
\text { lividum } \\
\text { NCTC } 9796\end{array}$} & \multicolumn{2}{|c|}{$\begin{array}{c}C . \\
\text { violaceum } \\
\text { NCTC } 9757\end{array}$} \\
\hline & & & & & $\begin{array}{l}T_{m(e)} \\
\left({ }^{\circ} \mathrm{C}\right)\end{array}$ & $\begin{array}{c}\text { rRNA } \\
\text { bind- } \\
\text { ing } \\
(\%)\end{array}$ & $\begin{array}{l}T_{m(e)} \\
\left({ }^{\circ} \mathrm{C}\right)\end{array}$ & $\begin{array}{c}\text { rRNA } \\
\text { bind- } \\
\text { ing } \\
(\%)\end{array}$ \\
\hline 146 & $\begin{array}{l}\text { Ace. pasteurianus subsp. } \\
\text { pasteurianus }\end{array}$ & NCIB 8945 & 58.3 & & & & 61.0 & 0.06 \\
\hline 147 & $\begin{array}{l}\text { Gluconobacter oxydans } \\
\text { subsp. suboxydans }\end{array}$ & NCIB 621 & 61.7 & & 59.5 & 0.10 & 59.5 & 0.12 \\
\hline 148 & $\begin{array}{l}\text { G. oxydans subsp. melano- } \\
\text { genus }\end{array}$ & NCIB 8086 & 60.6 & & 57.5 & 0.08 & & \\
\hline 149 & $\begin{array}{l}\text { G. oxydans subsp. melano- } \\
\text { genus }\end{array}$ & NCIB 8085 & 59.5 & & & & 59.5 & 0.11 \\
\hline 150 & Rhizobium leguminosarum & USDA $316 \mathrm{c} 10 \mathrm{a}$ & 61.4 & & 61.5 & 0.05 & & \\
\hline 151 & Rhi. leguminosarum & 5.0 & 61.1 & & 59.5 & 0.06 & & \\
\hline 152 & Rhi. meliloti & USDA 3DOa30 & 62.3 & & 58.5 & 0.06 & & \\
\hline 153 & Rhi. japonicum & USDA 316n10 & 63.3 & & 57.5 & 0.02 & & \\
\hline 154 & Rhi. japonicum & 3.1 & 63.9 & & 58.5 & 0.02 & & \\
\hline 155 & $\begin{array}{l}\text { Phyllobacterium } \\
\text { rubiacearum }\end{array}$ & LMG1 $t_{1}$ & 61.3 & & 59.5 & 0.04 & & \\
\hline 156 & Phy, myrsinacearum & LMG2 $t_{1}$ & 60.3 & & 60.5 & 0.05 & & \\
\hline 157 & Phy. myrsinacearum & LMG3 $t_{2}$ & 59.6 & & & & 57.5 & 0.05 \\
\hline 158 & Agrobacterium tumefaciens & ICPB TT111 & 60.4 & $\begin{array}{l}\text { Reference (J. De } \\
\text { Ley, unpub- } \\
\text { lished) }\end{array}$ & 59.5 & 0.07 & & \\
\hline 159 & Agr. tumefaciens & $\mathbf{B}_{2} \mathbf{a}$ & 61.1 & & 59.5 & 0.07 & & \\
\hline 160 & Agr. rhizogenes & ICPB TR7 & 61.4 & $\begin{array}{l}\text { Reference (J. De } \\
\text { Ley, unpub- } \\
\text { lished) }\end{array}$ & 57.5 & 0.06 & & \\
\hline 161 & Agr. rhizogenes & ICPB TR101 & 61.3 & & & & 59.5 & 0.04 \\
\hline 162 & Agrobacterium sp. & NA & 58.9 & & 58.0 & 0.05 & & \\
\hline 163 & $\begin{array}{l}\text { Zymomonas mobilis subsp. } \\
\text { mobilis }\end{array}$ & $\mathrm{Z1}$ & 48.9 & & 57.5 & 0.10 & & \\
\hline 164 & Paracoccus denitrificans & ATCC 17741 & 66.4 & Holotype (5) & 60.5 & 0.05 & 58.0 & 0.05 \\
\hline 165 & Par. denitrificans & ATCC 19367 & 67.4 & $\begin{array}{l}\text { Suggested cotype } \\
\text { for Micrococcus } \\
\text { denitrificans } \\
\text { (33) }\end{array}$ & 60.5 & 0.03 & & \\
\hline 166 & Mycoplana dimorpha & NCIB 9439 & 63.8 & & 58.5 & 0.06 & 57.5 & 0.05 \\
\hline 167 & $\begin{array}{l}\text { Flavobacterium meningo- } \\
\text { septicum }\end{array}$ & NCTC 10588 & 37.3 & & 56.5 & 0.05 & & \\
\hline 168 & F. arborescens & NCIB 8185 & 70.0 & Reference (5) & 58.5 & 0.04 & 55.0 & 0.04 \\
\hline 169 & F. esteraromaticum & NCIB 8186 & 65.1 & Reference (5) & 58.0 & 0.08 & & \\
\hline 170 & F. flavescens & NCIB 8187 & 67.2 & Reference (5) & 59.5 & 0.04 & & \\
\hline 171 & F. suaveolans & NCIB 8188 & 67.1 & Reference (5) & 62.0 & 0.03 & & \\
\hline 172 & Arthrobacter oxydans & CBRI 21010 & 62.4 & & 58.0 & 0.07 & & \\
\hline 173 & $\begin{array}{l}\text { Corynebacterium michiga- } \\
\text { nense }\end{array}$ & P 1468 & 70.5 & & 57.0 & 0.06 & & \\
\hline 174 & $\begin{array}{l}\text { Cor. sp. (Chromobacterium } \\
\text { viscosum) }\end{array}$ & NCTC 2416 & 58.0 & $\begin{array}{l}\text { Holotype for C. vis- } \\
\text { cosum (33) }\end{array}$ & 59.0 & 0.06 & 57.5 & 0.08 \\
\hline 175 & Microcyclus aquaticus & NCIB 9271 & & Type (5) & & & 56.5 & 0.02 \\
\hline 176 & Campylobacter fetus & B5 & & & 55.0 & 0.12 & & \\
\hline 177 & Cam. jejuni & M2 & 34.0 & & 57.0 & 0.10 & & \\
\hline 178 & Cytophaga marinoflava & ATCC 19326 & 38.4 & $\begin{array}{l}\text { Type ATCC (1974 } \\
\text { Catalog) }\end{array}$ & 56.0 & 0.04 & 54.0 & 0.04 \\
\hline 179 & Bacillus megaterium & 899 thy ${ }^{-}$ & 39.9 & & 56.5 & 0.17 & & \\
\hline 180 & Bac. subtilis & $\mathrm{BQ} 2$ & 47.7 & & 56.0 & 0.20 & & \\
\hline 181 & HeLa & & & & & 0.01 & & \\
\hline
\end{tabular}

${ }^{a}$ Included in the table are strain number, DNA base composition ( $\mathrm{G}+\mathrm{C}$ content), eventual type strain status, and properties of the DNA-rRNA hybrids with reference ${ }^{14} \mathrm{C}$-labeled rRNA from Chromobacterium violaceum NCTC 9757 and the renamed Janthinobacterium lividum NCTC 9796. The sequence numbers are not strain numbers; their purpose is only to locate the strains more easily on the similarity maps in Fig. 3 and 4 . The symbols $t_{1}$ or $t_{2}$ in some strain numbers indicate the colony type used, when more than one was observed in the original culture. Organisms with taxon names in quotation marks do not belong in that taxon. DNA base composition $(\mathrm{mol} \% \mathrm{G}+\mathrm{C}$ ) was determined by thermal denaturation. The nature of the different type and reference strains was checked in Bergey's Manual, 8th ed. (5), Sneath and Skerman (33), and the various collection catalogs. 
and Gram-stained cells. Cells were grown in mass cultures on the media as described before (16). We were unable to test $C$. marinum ATCC 19699, as it died both in our collection and in the ATCC before use. An authentic strain of $C$. chocolatum was not available for inclusion in the present study.

Preparation of $\left[{ }^{14} \mathrm{C}\right] \mathrm{rRNA}$. Reference $\left[{ }^{14} \mathrm{C}\right] \mathrm{rRNA}$ was prepared from the neotype strains $J$. lividum NCTC 9796 and C. violaceum NCTC 9757; it was purified and separated in $23 \mathrm{~S}$ and $16 \mathrm{~S}$ fractions as described before $(12,16,27)$. The organisms were grown under aeration at $28^{\circ} \mathrm{C}$ in $100 \mathrm{ml}$ of a liquid medium containing (weight per volume): $0.52 \%$ $\begin{array}{llllll}\mathrm{K}_{2} \mathrm{HPO}_{4}, & 0.27 \% & \mathrm{KH}_{2} \mathrm{PO}_{4}, \quad 0.2 \% & \mathrm{NaCl}, & 0.012 \%\end{array}$ $\mathrm{MgSO}_{4} \cdot 7 \mathrm{H}_{2} \mathrm{O}, 0.5 \%$ yeast extract (Difco), $0.6 \%$ glucose, and $100 \mu \mathrm{Ci}$ of $\left[{ }^{14} \mathrm{C}\right]$ uracil. The specific activity of $J$. lividum $23 \mathrm{~S}$ and $16 \mathrm{~S}\left[{ }^{14} \mathrm{C}\right] \mathrm{rRNA}$ was close to 4,000 $\mathrm{cpm} / \mu \mathrm{g}$; for $C$. violaceum $23 \mathrm{~S}$ and $16 \mathrm{~S}\left[{ }^{14} \mathrm{C}\right] \mathrm{rRNA}$ it was close to $3,000 \mathrm{cpm} / \mu \mathrm{g}$.

Preparation of high-molecular-weight DNA. DNA was prepared by a combination of the methods of Marmur $(25)$ and Kirby et al. $(21,22)$ as described by De Ley et al. (11). The final purification was carried out through a $\mathrm{CsCl}$ gradient in a $\mathrm{Ti}$ rotor for $20 \mathrm{~h}$ at $40,000 \mathrm{rpm}$ and at $20^{\circ} \mathrm{C}$ in a Beckman L2-65B preparative ultracentrifuge. The gradient was separated in a Isco fractionator, model 640 . The DNA fractions were pooled and dialyzed against 0.1 concentration of standard saline citrate (SSC) buffer at $4^{\circ} \mathrm{C}$. SSC buffer contains $0.15 \mathrm{M} \mathrm{NaCl}$ and $0.015 \mathrm{M}$ trisodium citrate (pH 7.0).

Fixation of single-stranded, high-molecularweight DNA on membrane filters. For the fixation of DNA on membrane filters, we followed the procedure as described by De Ley and Tytgat (14) by using Sartorius membrane filters (SM 11309). The DNAcontaining filters were preserved at $4^{\circ} \mathrm{C}$ in vacuo (12).

Saturation hybridization between $\left[{ }^{14} \mathrm{C}\right] \mathrm{rRNA}$ and filter-fixed DNA; thermal stability of the DNA-rRNA hybrids. For saturation hybridization, we followed the methods of De Ley et al. $(12,16)$. We determined two parameters: (i) $T_{m(e)}$, the temperature at which half of the DNA-rRNA hybrid was denatured, as a measure of its thermal stability, and (ii) the percent rRNA binding, i.e., the amount of $\left[{ }^{14} \mathrm{C}\right] \mathrm{rRNA}$ (in micrograms) hybridized in stringent conditions to $100 \mu \mathrm{g}$ of homologous or heterologous single-stranded, high-molecular-weight DNA.

Chemical determination of DNA on the filter. In each series of hybridizations a vial was included with buffer and a DNA filter, but without $\left[{ }^{14} \mathrm{C}\right] \mathrm{rRNA}$. After the simulated hybridization step, the remaining fixed DNA was released from the filter by the method of Meys and Schilperoort (26) and determined by the method of Burton (6).

Determination of DNA base composition ( $G+C$ content). Several of the $\mathrm{G}+\mathrm{C}$ content data in Table 1 have been published on previous occasions by this laboratory $(7-10,13,15)$. Other data were determined for the present paper by the thermal denaturation method (15).

Genome DNA similarities; genome DNA molecular weight. The degree of genome DNA similarities (expressed as \% D, degree of duplexing) was determined from the initial renaturation rate method
(11). The molecular weight of the genome DNA was determined by the method of Gillis et al. (19; equation 15 in reference 18 ).

\section{RESULTS}

The $16 \mathrm{~S}$ and $23 \mathrm{~S}$ fractions. $C$. violaceum and $J$. lividum $\left[{ }^{14} \mathrm{C}\right] \mathrm{rRNA}$ were readily separated in a 23S and a $16 \mathrm{~S}$ fraction (Fig. 1). Most of our experiments were carried out with the $23 \mathrm{~S}$ fraction. Both fractions probably have identical or very similar base sequences as $16 \mathrm{~S}$ fractions can be used without any noticeable differences in the results.

Comparison of DNA-rRNA cistrons. All the data are compiled in Table 1 . They will be evaluated extensively in Discussion. The data on $T_{m(e)}$ and percent rRNA binding were all obtained from the melting curves of the hybrids. These curves displayed a variety of shapes, varying from high to low $T_{m(e)}$, from high to low percent rRNA binding, and many values in between. Some examples are given in Fig. 2. One of us pointed out previously (16) that the percent rRNA binding, as defined above, is not a measure of the "rRNA cistron homology." The percent rRNA binding depends not only on the actual rRNA homology, but also on the size of the genome, its state of replication, and the number of rRNA cistrons per genome; the percent rRNA binding is a very useful parameter in separating taxa. The correlations between the data were better revealed by plotting $T_{m(e)}$ against percent RNA binding for each DNArRNA hybrid (Fig. 3 and 4). Table 2 summarizes data on reciprocal hybridizations between DNA from various Chromobacterium and Janthino-
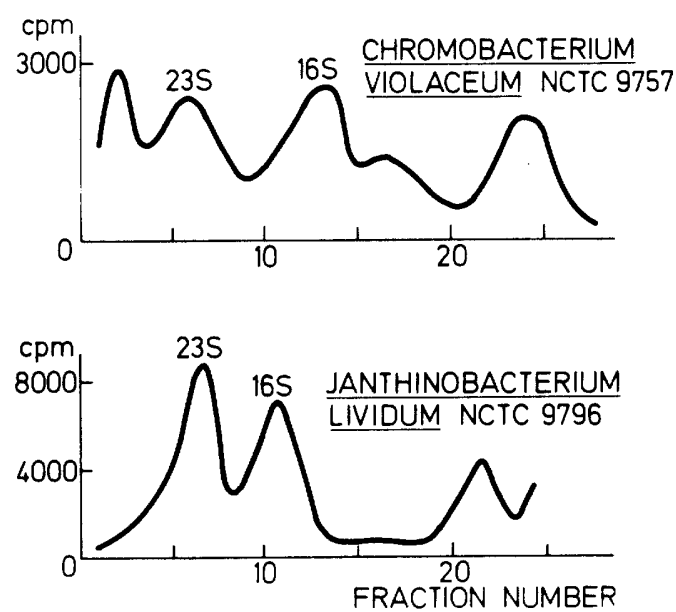

FIG. 1. Distribution of $\Gamma^{14} \mathrm{ClrRNA}$ in a linear 15 to $30 \%$ sucrose gradient, in $0.1 \mathrm{M}$ acetate buffer ( $p H$ 5.1), plus $0.05 \mathrm{M} \mathrm{NaCl}$; all solutions were treated with bentonite before use. 


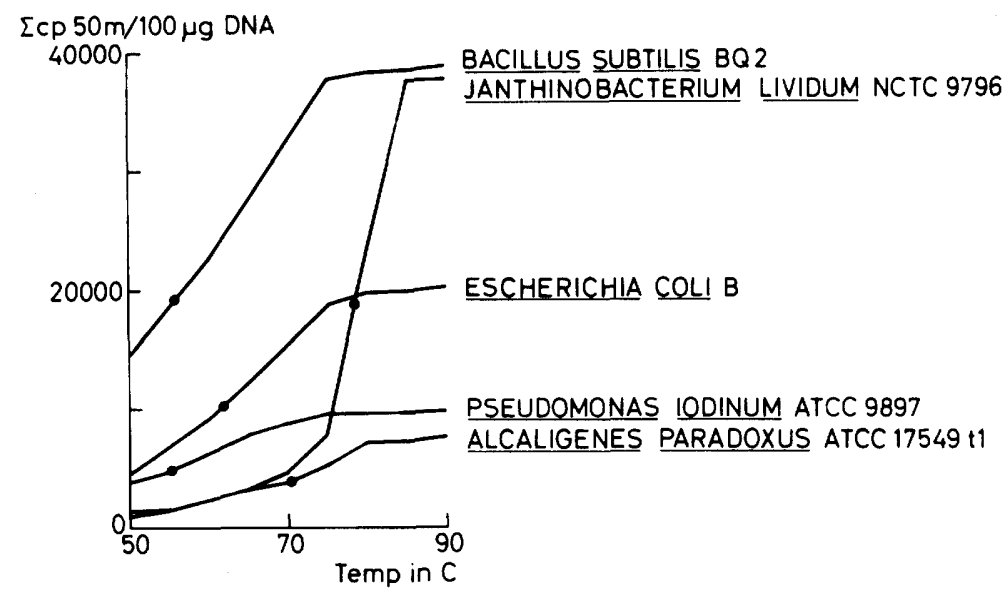

FIG. 2. Examples of melting curves of hybrids between ${ }^{14} \mathrm{C}$-labeled $23 \mathrm{~S}$ rRNA from Janthinobacterium lividum NCTC 9796 and filter-fixed DNA from various bacteria. The total amount of counts $/ 50$ min per 100 $\mu \mathrm{g}$ of DNA is a measure of the amount of hybrid denatured. The melting point $\left(T_{m(e)}\right)$ is the temperature at which half of the hybrid has been denatured and is represented by the central dot on each curve.

bacterium strains and $\left[{ }^{14} \mathrm{C}\right] \mathrm{rRN}$ from a variety of other genera.

Degree of genome DNA similarity. Six strains of the J. lividum taxon and four strains of the J. violaceum taxon were selected at random for DNA-DNA hybridizations. The main purpose was to determine the DNA similarity between both taxa: it is $(24 \pm 4) \% \mathrm{D}$ in stringent conditions (Table 3 ). The J. violaceum taxon seems to be more homogeneous ( 83 to $100 \% \mathrm{D}$ ) than the J. lividum taxon (48 to $95 \% \mathrm{D})$.

DNA genome size. The molecular complexity of the C. lividum genome DNA, with a molecular weight of $3.2 \times 10^{9}$, is some $15 \%$ larger than that of the $C$. violaceum genome, which has a molecular weight of $2.7 \times 10^{9}$.

\section{DISCUSSION}

rRNA cistron similarities. To make our results taxonomically more meaningful, we included as many type and reference strains as possible (Table 1).

For basic aspects of the discussion on the rRNA similarity maps (Fig. 3 and 4), we refer to a previous contribution from this laboratory (16). Each strain had a fixed position on each map within the limits of reproducibility of $T_{m(e)}$ $\pm 0.5^{\circ} \mathrm{C}$ and percent $\mathrm{rRNA}$ binding $\pm 0.015 \%$. Strains of the same taxon, which are phenotypically and genotypically very similar, were close together on the maps. There are many examples in Fig. 3 and 4, such as the strains of C. viola. ceum, J. lividum, Pseudomonas testosteroni, Alcaligenes paradoxus, etc. When many strains were included, the size and shape of the rRNA similarity area was a rough measure of the in- ternal heterogeneity of the taxon; for example, the Vibrionaceae appeared to be more heterogeneous than the Enterobacteriaceae. In several cases only one or a few strains of a taxon were included merely to locate the position of the genus on the map, not its area shape. A few genera were dispersed over several clearly separated rRNA areas. Pseudomonas was one example, it being divided over at least three areas: (i) the P. acidovorans-solanacearum- $\mathrm{H}_{2}$ oxidizers group; (ii) $P$. testosteroni; (iii) the P. fluorescens group; and (iv) some misnamed organisms such as " $P$." atlantica, " $P$." diminuta, and " $P$." iodinum, which do not belong in Pseudomonas. The explanation for the division in three main groups is that the present genus Pseudomonas is genetically and phenotypically very heterogeneous, and might in the future have to be split into at least two genera (De Ley and De Vos, manuscript in preparation). Another example was the Alcaligenes-Achromobacter group which was divided over the following rRNA areas: (i) the Alcaligenes-Achromobacter group sensu stricto (authentic Alcaligenes faecalis, Alc. odorans, Alc. denitrificans, Ach. xylosoxidans, and a few more); (ii) the $\mathrm{H}_{2^{-}}$ oxidizing Alcaligenes paradoxus; and (iii) the marine organisms "Alc." pacificus, "Alc." venustus, "Alc." aestus, and "Alc." aquamarinus. The explanation for the apparent heterogeneity of Alcaligenes is that this genus has always been, and still is, a taxonomic wastebasket full of misnamed organisms. Extensive phenotypical data (Kersters and De Ley, manuscript in preparation) allowed us to predict that group (iii) does not belong in Alcaligenes. It is interesting 


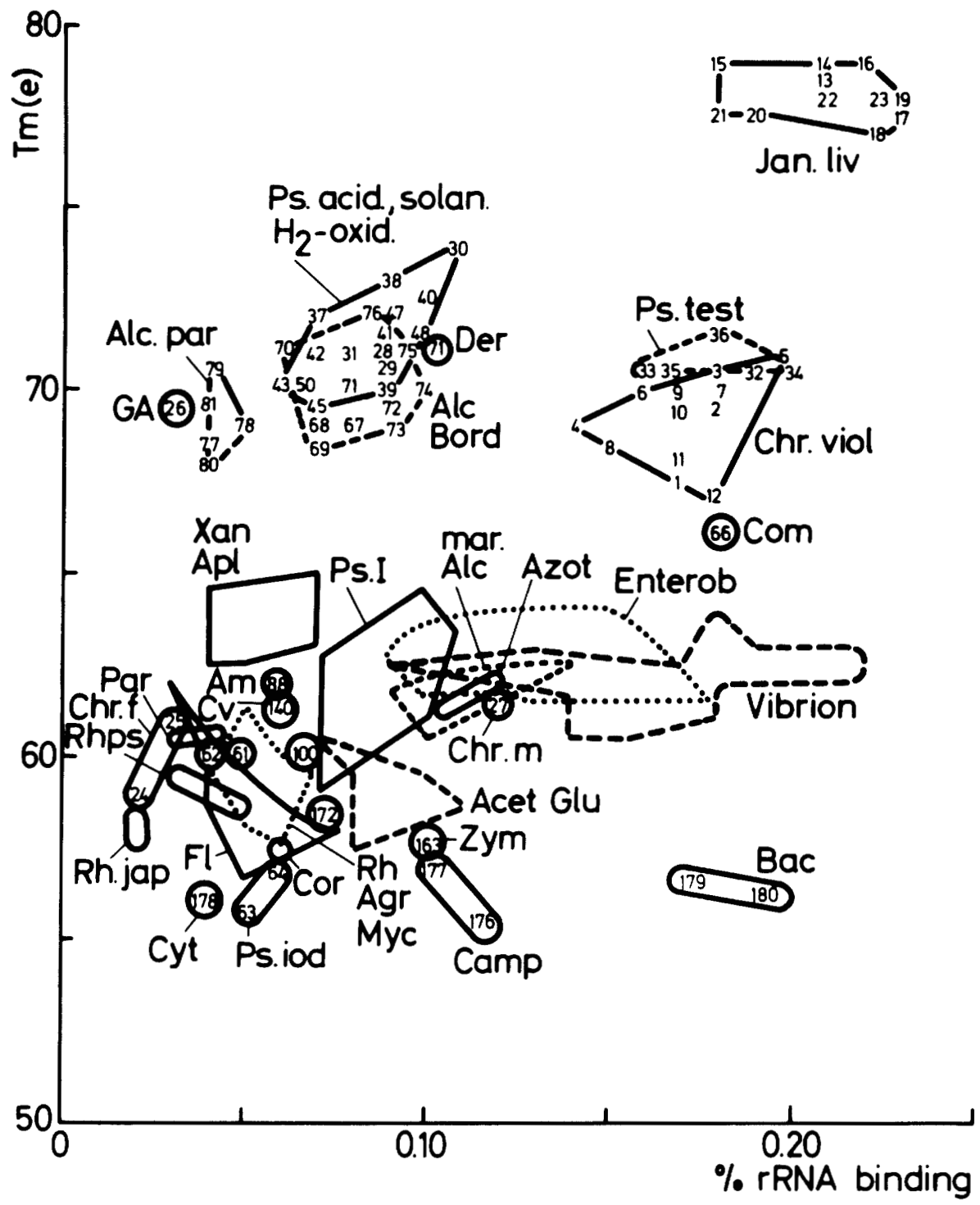

FIG. 3. Similarity map of hybrids between the ${ }^{14}$ C-labeled $23 S$ rRNA fraction of Janthinobacterium (Chromobacterium) lividum NCTC 9796 and DNA from a variety of bacteria. $T_{m(e)}$ and percent $r R N A$ binding are as defined in the text. Strains are represented by their sequence number (Table 1), which is not the strain number. To simplify the drawing below $65^{\circ} \mathrm{C}$, the sequence numbers of strains were not shown in areas where several taxa overlapped. The positions of all strains belonging phenotypically to the same taxon (usually a genus) are surrounded by a closed line; this line is not the ultimate border. Abbreviations: Acet: Acetobacter; Agar: Agarbacterium; Agr: Agrobacterium; Alc: Alcaligenes; Alc. par: Alcaligenes paradoxus; Am: Azomonas; Apl: Aplanobacter; Ar: Arthrobacter; Azot: Azotobacter; Bac: Bacillus; Bord: Bordetella; Camp: Campylobacter; Chr. f: "Chromobacterium folium;" Chr. m: "Chromobacterium marismortui;" Chr. viol: Chromobacterium violaceum; Com: Comamonas; Cor: Corynebacterium; Cv: Cellvibrio; Cyt: Cytophaga; Der: Derxia; Enterob: Enterobacteriaceae; Fl: Flavobacterium; GA: "Chromobacterium lividum" GA; Glu: Gluconobacter; Jan. liv: Janthinobacterium lividum; mar. Alc: marine "Alcaligenes;” Micr: Microcyclus; Myc: Mycoplana; Par: Paracoccus; Phyl: Phyllobacterium; Ps. acid., solan., $H_{2}$-oxid: Pseudomonas acidovorans, Ps. solanacearum, $\mathrm{H}_{2}$-oxidizing pseudomonads; Ps. I: Pseudomonas section I; Ps. iod: "Pseudomonas iodinum;" Ps. test: Pseudomonas testosteroni; Rh: Rhizobium; Rh. jap: Rhizobium japonicum; Rhps: Rhodopseudomonas; Sp. sin: Spirillum sinuosum; Vibrion: Vibrionaceae; Xan: Xanthomonas; Zym: Zymomonas. 


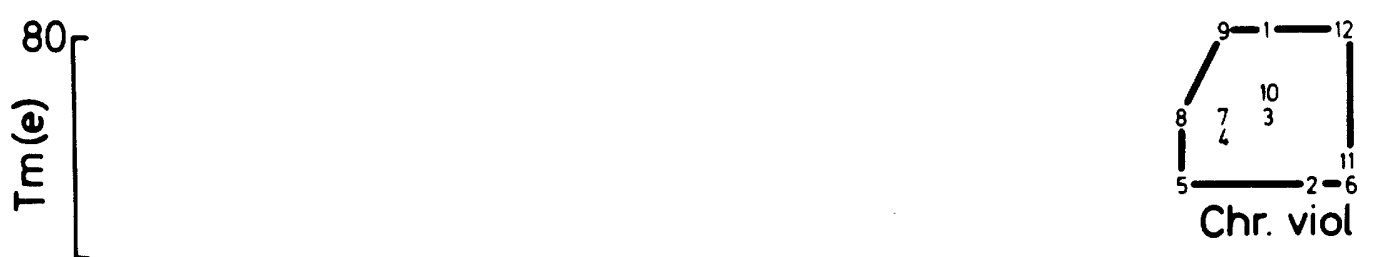

Ps. acid., solan., $\mathrm{H}_{2}$-oxid

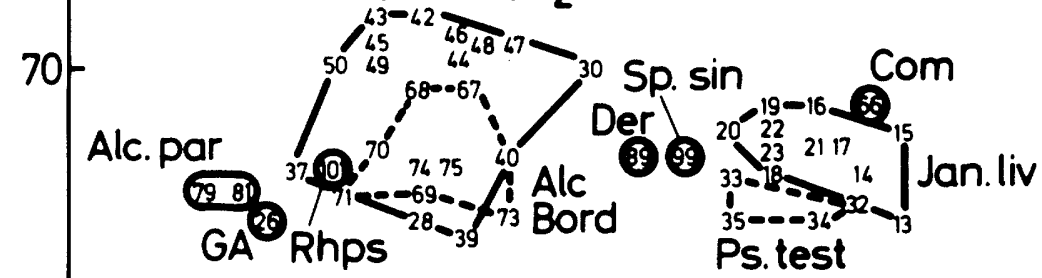

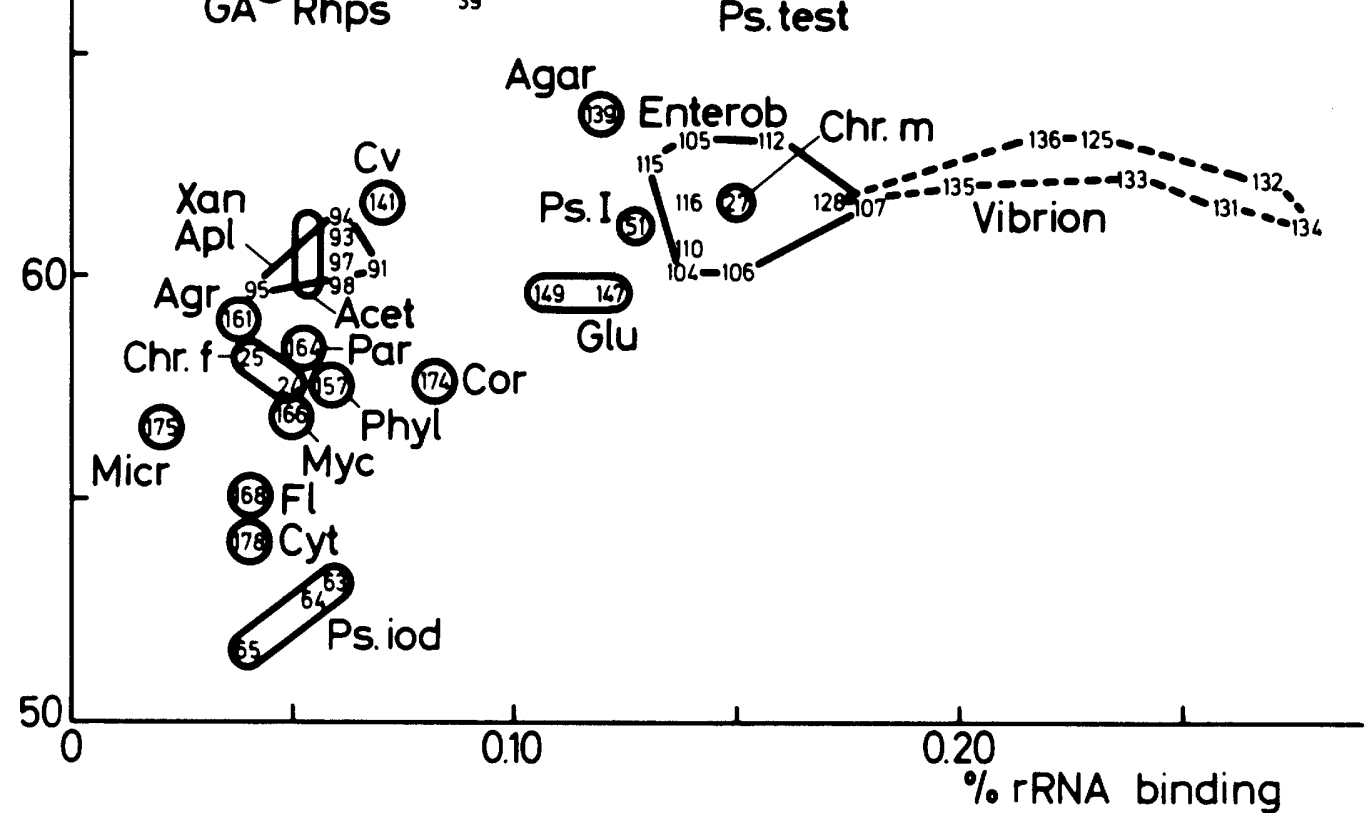

FIG. 4. Similarity map of hybrids between the ${ }^{14} \mathrm{C}$-labeled $23 S$ rRNA fraction of Chromobacterium violaceum NCTC 9757 and DNA from a variety of bacteria. See legend to Fig. 3 for additional information.

to note that Bordetella bronchiseptica, which is phenotypically so similar to authentic Alcaligenes, is in the same rRNA area, and that the $\mathrm{H}_{2}$-oxidizing Pseudomonas and Alcaligenes strains are both in the same rRNA region. Xanthomonas and Aplanobacter populi were located in the same rRNA area, in excellent agreement with conclusions from other experiments (De Ley and De Vos, manuscript in preparation) that both genera are either very closely related or perhaps identical. Spirillum and Rhodopseudomonas rRNA areas were heterogeneous, in agreement with phenotypical heterogeneity (5).
The position of other genera will be commented on below.

Proposal for an improved nomenclature of the chromobacteria. The present taxonomy of Chromobacterium is almost exclusively the result of the numerical analysis of phenotypical features of these organisms and has been described extensively and thoroughly by Sneath (29-32). The chromobacteria contain two taxa which were presented up to now as two species, C. violaceum and C. lividum, of one genus. Sneath repeatedly stressed that the phenotypic data did not unequivocally allow a decision to 
TABLE 2. Hybridizations between DNA from various C. violaceum and J. lividum strains and from a few misnamed chromobacteria, with ${ }^{14} \mathrm{CJ}$ rRNA from various reference strains ${ }^{a}$

\begin{tabular}{|c|c|c|c|c|c|c|c|c|c|c|c|c|c|c|c|c|c|c|c|c|c|c|}
\hline \multirow{2}{*}{$\begin{array}{l}\text { Source of }\left[{ }^{14} \mathrm{C}\right] \mathrm{rRNA} \\
\text { DNA from: }\end{array}$} & \multicolumn{2}{|c|}{$\begin{array}{c}\text { Pseudomonas } \\
\text { solanacearum } \\
\text { NCPPB } 325\end{array}$} & \multicolumn{2}{|c|}{$\begin{array}{c}\text { Pseudo- } \\
\text { monas } \\
\text { acidovor- } \\
\text { ans ATCC } \\
15668\end{array}$} & \multicolumn{2}{|c|}{$\begin{array}{l}\text { Alcali- } \\
\text { genes } \\
\text { faecalis } \\
\text { NCIB } \\
8156\end{array}$} & \multicolumn{2}{|c|}{$\begin{array}{c}\text { Pseudo- } \\
\text { monas } \\
\text { fluores- } \\
\text { cens } \\
\text { ATCC } \\
13525\end{array}$} & \multicolumn{2}{|c|}{$\begin{array}{c}\text { Xantho- } \\
\text { monas } \\
\text { campes- } \\
\text { tris } \\
\text { NCPPB } \\
528\end{array}$} & \multicolumn{2}{|c|}{$\begin{array}{l}\text { Azotobac- } \\
\text { ter chroo- } \\
\text { coccum } \\
\text { NCIB } \\
8002\end{array}$} & \multicolumn{2}{|c|}{$\begin{array}{c}\text { Esche- } \\
\text { richia coli } \\
\text { B }\end{array}$} & \multicolumn{2}{|c|}{$\begin{array}{l}\text { Agrobac- } \\
\text { terium } \\
\text { rhizo- } \\
\text { genes } \\
\text { ICPB } \\
\text { TR7 }\end{array}$} & \multicolumn{2}{|c|}{$\begin{array}{l}\text { Agrobac- } \\
\text { terium } \\
\text { tumefa- } \\
\text { ciens } \\
\text { ICPB } \\
\text { TT111 }\end{array}$} & \multicolumn{2}{|c|}{$\begin{array}{l}\text { Glucono- } \\
\text { bacter ox- } \\
\text { ydans } \\
\text { NCIB } \\
9013\end{array}$} & \multicolumn{2}{|c|}{$\begin{array}{c}\text { Acetobac- } \\
\text { ter aceti } \\
\text { NCIB } \\
8621\end{array}$} \\
\hline & $T_{m(t e)^{b}}^{b}$ & $\%^{c}$ & $T_{m(e)}$ & $\%$ & $T_{m(e)}$ & $\%$ & $T_{m(e)}$ & $\%$ & $T_{n !(e)}$ & $\%$ & $T_{n i(e)}$ & $\%$ & $T_{n t(e)}$ & $\%$ & $T_{n t(c)}$ & $\%$ & $T_{m(e)}$ & $\%$ & $T_{m(e)}$ & $\%$ & $T_{m(e)}$ & $\%$ \\
\hline
\end{tabular}

Chromobacterium violaceum NCTC 868

NCTC 9370

NCTC 9371

NCTC 9373

NCTC 9374

NCTC 9695

NCTC 9696

NCTC 9757

Janthinobacterium livi-

dum

NCTC 8661

NCTC 9796

ATCC 14487

DA (Sneath)

HD (Sneath)

MB (Sneath)

RU (Sneath)

"C. lividum" NCTC 10590

"C. lividum" NCTC 10591

"C. marismortui" ATCC$$
17056
$$

$\begin{array}{ll}67 & 0.14 \\ 70 & 0.14\end{array}$

$70 \quad 0.14$

0.14

$\begin{array}{ll}63 & 0.14 \\ 64.5 & 0.16\end{array}$

$65.5 \quad 0.16$

$\begin{array}{llllll}70.5 & 0.15 & & & 68 & 0.19\end{array}$

$70.5 \quad 0.15$

$\begin{array}{ll}72 & 0.20\end{array}$

$\begin{array}{lllll}67 & 0.21 & 64.5 & 0.11 & 64\end{array}$

$\begin{array}{lllll}0.14 & 64.5 & 0.17 & 61.5 & 0.11\end{array}$

$60 \quad 0.15$

$\begin{array}{llll}73 & 0.13 & 70.5 & 0.12 \\ 72.5 & 0.16 & 71 & 0.12\end{array}$

20.16

$\begin{array}{llllll} & & 64.5 & 0.14\end{array}$

$\begin{array}{llllllll}61.5 & 0.07 & 62.5 & 0.11 & 64 & 0.14 & 65 & 0.15\end{array}$

$\begin{array}{ll}64 & 0.16\end{array}$

$62.5 \quad 0.10$

$\begin{array}{llll}71 & 0.18 & 64.5 & 0.11\end{array}$

$\begin{array}{llll}72 & 0.13 & 71 & 0.08\end{array}$

$\begin{array}{ll}70.5 & 0.16\end{array}$

$\begin{array}{ll}62.5 & 0.12\end{array}$

$70.5 \quad 0.17$

$\begin{array}{lllllll}\text { “C. lividum” GA (Sneath) } & 66.5 & 0.01 & 75.5 & 0.04 & 66.0 & 0.05\end{array}$

${ }^{a}$ From unpublished data of J. De Ley, J. De Smedt, P. De Vos, M. Gillis, P. Segers, and R. Tytgat

${ }^{b} T_{m(e)}$ is expressed in ${ }^{\circ} \mathrm{C}$.

$\%$, Percent rRNA binding. 
TABLE 3. Genome DNA similarities within and between the J. lividum and C. violaceum taxa ${ }^{a}$

\begin{tabular}{|c|c|c|c|c|c|c|c|c|c|}
\hline $\begin{array}{c}\text { Strain } \\
\text { no. }\end{array}$ & & & & & & & & & \\
\hline $\begin{array}{r}\text { NCTC } \\
9796 \\
\end{array}$ & 100 & & & & & & & & \\
\hline $\begin{array}{l}\text { HA } \\
\text { (Sneath) }\end{array}$ & 95 & 100 & & & & & & & \\
\hline $\begin{array}{l}\text { ATCC } \\
14487 \\
\end{array}$ & 54 & 57 & 100 & & & & & & \\
\hline $\begin{array}{l}\text { MB } \\
\text { (Sneath) }\end{array}$ & 66 & 66 & 55 & 100 & & & & & \\
\hline $\begin{array}{l}\text { RU } \\
\text { (Sneath) }\end{array}$ & 65 & 48 & & 70 & 100 & & & & \\
\hline $\begin{array}{r}\text { NCTC } \\
7150 \\
\end{array}$ & 58 & 74 & 51 & & & 100 & 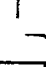 & & \\
\hline $\begin{array}{c}\text { NCTC } \\
9757 \\
\end{array}$ & 24 & 21 & 28 & & & & 100 & & \\
\hline $\begin{array}{r}\text { NCTC } \\
9372 \\
\end{array}$ & 32 & 23 & & & & & 87 & $100 \mid$ & \\
\hline $\begin{array}{r}\text { NCTC } \\
9377 \\
\end{array}$ & 25 & 30 & & & & & 100 & $100 \mid$ & \\
\hline $\begin{array}{r}\text { NCTC } \\
8684\end{array}$ & 18 & 20 & 26 & & & & 83 & 100 & 100 \\
\hline
\end{tabular}

${ }^{a}$ Expressed in percent versus homologous degree of binding (100\%). Initial renaturation rate method in stringent conditions (11).

be made whether both taxa are different at the species or at the genus level. We quote: "It is possible that the genus is not a very natural taxon ..." (32); "The species are almost as different from one another as are many genera" (32); "One might therefore consider whether the two species of Chromobacterium should be raised to the rank of genera, ..." (31). Leifson (24) likewise pointed out that the species of Chromobacterium were very different and suggested that they might be raised to generic rank.

The rRNA similarity maps (Fig. 3 and 4) showed clearly that the $C$. violaceum and $C$. lividum clusters were likewise different, that they exchanged places depending on the reference $\left[{ }^{14} \mathrm{C}\right] \mathrm{rRNA}$ used, and that all other taxa remained approximately in about the same position. All C. lividum strains and all C. violaceum strains formed tight separate clusters around their respective neotype strains. The rRNA cistrons of both taxa were quite different both in nucleotide sequence $\left(T_{m(e)}\right)$ and in percent rRNA binding. In fact they were about as different from each other as from Pseudomonas sections II and III, or as Agrobacterium, Acetobacter, and Zymomonas are from each other (16), or as Escherichia is from Vibrio (De Ley, Tytgat, De Smedt, and De Vos, manuscript in preparation). The conclusion was therefore unavoidable that both taxa $C$. violaceum and $C$. lividum are not species of one genus, but are separate genera. The long list of phenotypic differences
(Table 4) and the low degree of DNA relatedness (about 24\% D, Table 3) between both taxa strongly supported this suggestion.

We propose to retain and emend the name Chromobacterium Bergonzini 1881, 153 for the C. violaceum taxon only (Rule 39a and 35 of the International Code of Nomenclature of Bacteria [23]). Its diagnostic characters as given in Bergey's Manual, 8th ed. (32), have to be emended by the features from Table 4 . The type and sole species is C. violaceum Bergonzini 1881, 153, emend. mut. char. Sneath 1956, 79, emend. mut. char. De Ley et al. (present paper), (Rule $39 \mathrm{~b})$ with the same description as the genus. The neotype strain remains MK = NCTC 9757 $=$ NCIB $9131=$ ATCC $12472=$ Sneath D 252.

For the C. lividum taxon we propose a new genus name. Previously this taxon belonged in the genera Bacillus, Bacterium, and Chromobacterium. None of these is obviously suited as a new genus name. The most striking feature of these organisms is the violet color. Therefore we propose Janthinobacterium, genus novum, from janthinus, L. adj. violet-colored. The basic description is the same as for Chromobacterium in Bergey's Manual, 8th ed. (32), but has to be modified by the typical features in Table 4 . The type and sole species is J. lividum comb. nov. (Rule 41a) with a description as for the genus. The neotype strain is NCTC $9796=$ NCIB 9130 $=$ ATCC $12473=$ CCM $160=$ Sneath HB and D303 = Hans H-24 (32). Some other members of this genus are listed in Table 1. DNA-rRNA hybridizations with strain ATCC 14487 showed it to be a regular member of J. lividum. Nevertheless it is an unusual organism, as it grows preferentially at $4^{\circ} \mathrm{C}$, not at room temperature, and has a low $\mathrm{G}+\mathrm{C}$ content of $61.2 \mathrm{~mol} \%$; its DNA-DNA hybridizations are the lowest of the taxon. We assume all this to be due to considerable deletions in the genome, since the genome DNA molecular weight is $2.65 \times 10^{9}, 18 \%$ smaller than the average genome size of the J. lividum taxon. The facts that both genera Chromobacterium emend. and Janthinobacterium have many phenotypical features in common (violacein biosynthesis is but one of them) and that their genome DNAs hybridize for about $24 \%$ are good indications that they descended from common ancestors.

Misnamed strains. C. amethystinum ATCC 6915 has to be renamed and belongs in J. lividum (Table 1) in agreement with phenotypic findings of Sneath (personal communication). The rRNA cistrons of the following organisms were quite different from authentic Chromobacterium and Janthinobacterium rRNA cistrons. These organisms have been misnamed and do not belong in either Chromobacterium or Jan- 
TABLE 4. Phenotypic features differentiating the genera Chromobacterium and Janthinobacterium ${ }^{a}$

\begin{tabular}{|c|c|c|}
\hline Feature & Chromobacterium & Janthinobacterium \\
\hline Occurrence & Predominates in the tropics & $\begin{array}{l}\text { Predominates in temperate re } \\
\text { gions }\end{array}$ \\
\hline Pathogenicity & $\begin{array}{l}\text { Occasionally responsible for py- } \\
\text { ogenic or septicemic infections } \\
\text { of man and animals }\end{array}$ & Probably not pathogenic \\
\hline Grows best at: & $30-35^{\circ} \mathrm{C}$ ("mesophilic") & $25^{\circ} \mathrm{C}$ ("psychrophilic") \\
\hline Growth at $37^{\circ} \mathrm{C}$ & + & - \\
\hline Aerobiosis & Facultatively aerobic & Strictly aerobic \\
\hline Size of rods $(\mu \mathrm{m})$ & $0.6-0.9$ by $1.5-3$ & $0.8-1.2$ by $2.5-6$ \\
\hline Violet ring in broth & + (with fragile pellicle) & Usually viscous and frondlike \\
\hline Production of HCN & + & - \\
\hline Turbidity from egg-yolk & + & - \\
\hline $\begin{array}{l}\text { Proteolysis, hemolysis, and chitino- } \\
\text { lysis }\end{array}$ & Moderate to strong & Poor \\
\hline \multicolumn{3}{|l|}{$\begin{array}{l}\text { Acid from (in Hugh \& Leifson me- } \\
\text { dium): }\end{array}$} \\
\hline L-Arabinose & - & Almost always + \\
\hline Galactose & - & Almost always + \\
\hline$m$-Inositol & - & Almost always + \\
\hline Xylose & - & Almost always + \\
\hline Lactose & - & Often + \\
\hline Mannitol & - & Often + \\
\hline Cellobiose & - & Often + \\
\hline Inulin & - & Often + \\
\hline Sucrose & Rarely + & Often + \\
\hline Glycerol & Rarely + & Often + \\
\hline Trehalose & + & - \\
\hline Hydrolysis of esculin & - & + \\
\hline Arginine decarboxylase & + & Rarely + \\
\hline Arginine dihydrolase & Variable & - \\
\hline Melanine from phenylalanine & Often & Usually - \\
\hline Visible gas from $\mathrm{NO}_{3}^{-}$ & - & Sometimes + \\
\hline Methylene blue reduction & + (often weak) & Seldom + \\
\hline Growth on citrate and $\mathrm{NH}_{3}$ & $+($ but slow $)$ & Usually rapid \\
\hline \multicolumn{3}{|l|}{ Growth on: } \\
\hline L-Leucine & - & + \\
\hline Ornithine & + & - \\
\hline Phenylalanine & + & - \\
\hline $\mathrm{G}+\mathrm{C}$ range $(\mathrm{mol} \%)$ & $65.2-67.6$ & $65.1-66.1$ \\
\hline Average mol wt of genome DNA & $2.7 \times 10^{9}$ & $3.2 \times 10^{9}$ \\
\hline
\end{tabular}

${ }^{a}$ The phenotypic data are from Sneath (29-32) the G+C content values are from De Ley et al. (7, 15; unpublished results), and the genome sizes are from the present paper.

thinobacterium. This conclusion is corroborated by other data.

"C. lividum" ("C." folium) NCTC 10590 and NCTC 10591 were isolated from germinated seeds, and are present in leaf nodules of Psychotria nairobensis and Ardisia crispa (1). Their rRNA cistrons were more closely related to the agrobacterial and rhizobial rRNA cistrons (16; Tables 1 and 2). These and other features (16) suggested that both strains belong in the family of the Rhizobiaceae, together with Agrobacterium, Rhizobium, Mycoplana, Phyllobacterium, and a few other organisms.

The exact taxonomic position of " $C$. lividum" GA has been a problem for several years, for its $\mathrm{G}+\mathrm{C}$ content was noticeably different from the base composition of authentic J. lividum strains
(15) and it is yellow. The rRNA parameters of strain GA were outside the Chromobacterium and Janthinobacterium areas in the similarity maps. Strain GA belongs to neither of these genera. Since the parameters were more similar to $P$. acidovorans reference rRNA (Table 2), strain GA may be a member of Pseudomonas section II or III (17).

Several phenotypical features (halophily, flagellar arrangement, colorless to pale beige colonies, etc.) set C. marismortui ATCC 17056 apart from Chromobacterium and Janthinobacterium. In Bergey's Manual, 7th ed. (2), C. marismortui was still a regular species of Chromobacterium. In Bergey's Manual, 8th ed., C. marismortui was temporarily maintained as a species incertae sedis in the same genus (32). The rRNA 
parameters (Tables 1 and 2) definitely move the holotype of this taxon outside Chromobacterium and Janthinobacterium. C. marismortui ATCC 17056 is either a border case of Pseudomonas section I or a member of a genus closely related to the latter taxon (Table 2).

"Pseudomonas" (Chromobacterium) iodinum continues to resist taxonomic identification. It is temporarily a species incertae sedis of Chromobacterium (32). Sneath (31) concluded that it was a gram-positive diphtheroid organism. Our rRNA data remove it definitely from Chromobacterium, Janthinobacterium, Pseudomonas, and nearly all of the other genera listed in Table 1. Its eventual relationship with the coryneforms remains to be explored.

"C. indicum-rubrum" NCTC 2847 has been renamed Serratia marcescens. The absorption peak of the extracted pigment was the same as that of prodigiosin from authentic Serratia (M. Gillis and De Ley, unpublished data). The properties of the rRNA hybrids of this strain fell correctly within the area of the Enterobacteriaceae (Table 1).

Sneath (31) found that " $C$." viscosum NCTC 2416 does not belong to the chromobacteria. We found that the properties of its rRNA hybrids are quite different from Chromobacterium and Janthinobacterium. The exact taxonomic position of this strain is unknown. We received it as Corynebacterium sp.

Relationship of Chromobacterium and Janthinobacterium with other genera. The relationship between the former genus Chromobacterium Bergonzini and other genera has always been obscure. The early taxonomic wanderings of these bacteria are of historical interest only and will not be discussed here. In Bergey's Manual, 6th ed. (3) and 7th ed. (4), this genus turned up quite unjustifiably in the family of the Rhizobiaceae together with Rhizobium and Agrobacterium. Heberlein et al. (20) showed by DNA-DNA hybridization that both J. lividum and $C$. violaceum taxa were far removed from the latter genera and proposed to remove the chromobacteria from the family Rhizobiaceae. Our rRNA data confirmed this conclusion. In Bergey's Manual, 8th ed. (32), Chromobacterium Bergonzini was located in Part 8 (gramnegative, facultatively anaerobic rods) as a genus of uncertain affiliation in the vicinity of the Enterobacteriaceae and Vibrionaceae.

According to Fig. 3 and 4 the percent rRNA binding of both Chromobacterium and Janthinobacterium are most similar to the Enterobacteriaceae, the Vibrionaceae, P. testosteroni, Comamonas percolans NCIB 8193, and Bacillus. However, the percent rRNA binding cannot be a measure of overall taxon relatedness, be- cause it is not a measure of ribosomal DNA homology (see above) and because of the enormous differences in phenotypic features and in $\mathrm{G}+\mathrm{C}$ content between most of these taxa. On the contrary, a previous study with rRNA cistrons of Agrobacterium (16) demonstrated that $T_{m(e)}$ is a more valuable parameter as it displayed a clear-cut correlation with the overall phenotypic similarity. The rRNA cistron areas of both Chromobacterium and Janthinobacterium overlap (Fig. 3 and 4) with those of $P$. testosteroni. This taxon is a member of Pseudomonas section III (representative strains are $P$. acidovorans, $P$. delafieldii, $P$. facilis, and $P$. solanacearum) (17), both on phenotypic grounds (34) and by rRNA homology (competitive method) (28). At the same $T_{m(e)}$ level (Tables 1 and 2), we noticed representative strains of Pseudomonas section II ( $P$. cepacia and P. marginata), of the authentic Alcaligenes-Achromobacter group (Alc. faecalis, Alc. odorans, Alc. denitrificans, Ach. xylosoxidans) (Kersters and De Ley, manuscript in preparation), Bordetella bronchiseptica, and the $\mathrm{H}_{2}$-oxidizing Alcaligenes eutrophus and Alcaligenes paradoxus. All of these strains are at about the same $T_{m(e)}$ level, i.e., an average of $71^{\circ} \mathrm{C}$ versus $\mathrm{J}$. lividum $\left[{ }^{14} \mathrm{C}\right] \mathrm{rRNA}$ and $68.5^{\circ} \mathrm{C}$ versus $C$. violaceum $\left[{ }^{14} \mathrm{C}\right] \mathrm{rRNA}$. On the above grounds we concluded that the rRNA cistrons of Chromobacterium, Janthinobacterium, most or all of Pseudomonas sections II and III, the authentic Alcaligenes-Achromobacter group, Bor detella bronchiseptica, the $\mathrm{H}_{2}$-oxidizing polarly flagellated Pseudomonas, and peritrichously flagellated Alcaligenes are phylogenetically more similar to each other than to other genera; these taxa constitute one large rRNA family. Figure 5 summarizes the relationships between the $T_{m(e)}$ values. This similarity extends to the genotypic level, as most organisms have a high $\mathrm{G}+\mathrm{C}$ content in the range 62 to $70 \mathrm{~mol} \%$ (Table 5 ); the Alc. faecalis group and $P$. lemoignei are somewhat lower with 56.5 to $59.4 \mathrm{~mol} \% \mathrm{G}+\mathrm{C}$. Many of these genera share some common phenotypical features: they are gram-negative, rigidly bound rods, usually 0.5 to 1 by 1 to $4 \mu \mathrm{m}$, without resting stages, motile (by polar, peritrichous, or both types of flagella); they are chemoorganotrophic (some are facultatively chemolithotrophic for the oxidation of $\mathrm{H}_{2}$ ); the metabolism is usually respiratory with $\mathrm{O}_{2}$ as the universal electron acceptor; they frequently use organic acids, or glucose, and some other carbohydrates; growth factors are usually not required; they are soil and water bacteria, occasionally causing infections in mammals, in plants, or food spoilage. The phenotypic descriptions of some of these taxa are incompletely known. Our conclusions suggest that the phenotypic features of the taxa 


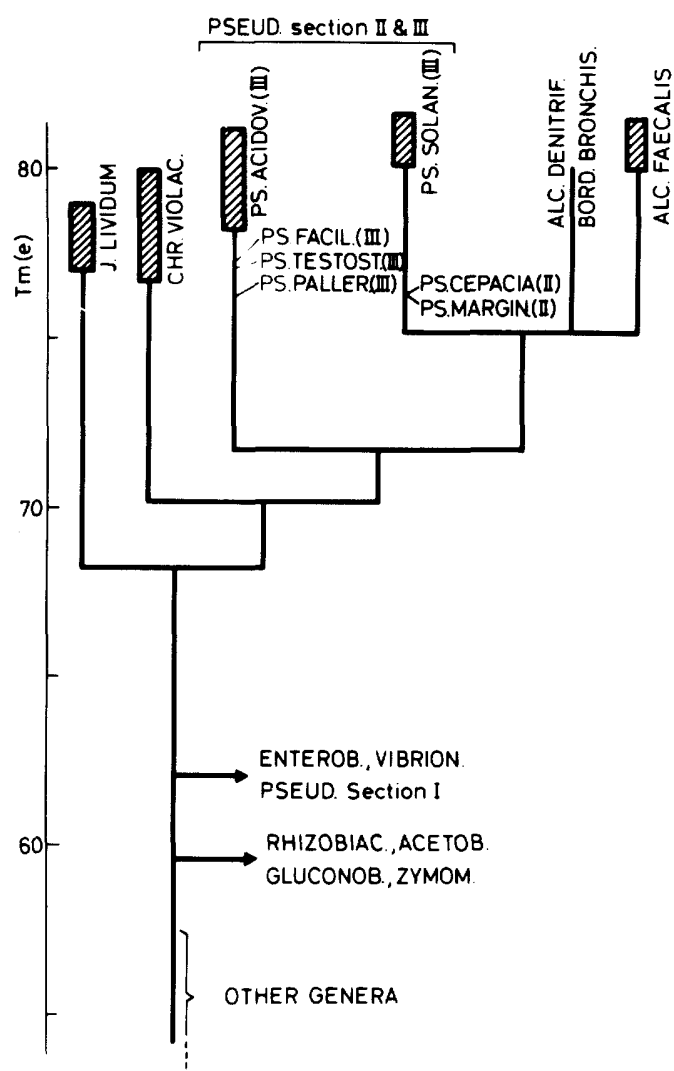

FIG. 5. Levels of $T_{m(e)}$ similarities within the $R$ RA family of Chromobacterium, Janthinobacterium, Pseudomonas (sections $I I$ and III), the authentic Alcaligenes, and Bordetella bronchiseptica. The next set of rRNA families joins at an average $T_{m(e)}$ of $62.1^{\circ} \mathrm{C}$, and consists of the Enterobacteriaceae, the Vibrionaceae, Pseudomonas (section I), and a few other taxa. The next lower set of rRNA families is at an average $T_{m(e)}$ of $59.6^{\circ} \mathrm{C}$ and consists of the Rhizobiaceae (15), the acetic acid bacteria, and a few other taxa. All remaining taxa, both gram negative and gram positive, which we investigated are farther removed, with a $T_{m(e)}$ below $59^{\circ} \mathrm{C}$. The data for the graph are from the present paper and from unpublished experiments from this laboratory (De Ley, De Vos, Segers). They were clustered by the unweighted average linkage method. The hatched areas on top of most branches represent the range of $T_{m(e)}$ values of the reference taxon.

in this rRNA family should be reexamined more comparatively.

The rRNA cistrons of all other taxa have a lower $T_{m(e)}$. They contain more mismatchings and are thus less related to the Chromobacterium and Janthinobacterium rRNA family. From the present paper and from unpublished experiments we can see three layers of $T_{m(e)}$ similarities in these remaining genera. (i) Be-
TABLE 5. DNA base composition range of taxa within the rRNA family of Chromobacterium, Janthinobacterium, Pseudomonas sections II and III, Alcaligenes - Achromobacter, and Bordetella bronchiseptica ${ }^{a}$

\begin{tabular}{|c|c|}
\hline Tax & $\mathrm{Mol} \% \mathrm{G}+\mathrm{C}$ \\
\hline $\begin{array}{l}\text { um } \\
\text { ium }\end{array}$ & .1 \\
\hline $\begin{array}{c}\text { acidovorans group (acidovorans, le- } \\
\text { moignei, delafieldii) } \ldots \ldots \ldots \ldots \ldots\end{array}$ & \\
\hline & \\
\hline is, flava, palleronii) & $\begin{array}{l}61.7-67.3 \\
66-68 \\
66-68.6\end{array}$ \\
\hline lca & \\
\hline & \\
\hline II $(A l c . d$ & $63.9-69.8$ \\
\hline $\begin{array}{c}\mathrm{H}_{2} \text {-oxidizing Alcaligenes (eutrophus, } \\
\text { paradoxus) } \ldots \ldots \ldots \ldots \ldots \ldots \ldots \ldots \ldots\end{array}$ & \\
\hline $\begin{array}{l}\text { orc } \\
\text { om }\end{array}$ & $\begin{array}{l}68.2- \\
64.3\end{array}$ \\
\hline
\end{tabular}

${ }^{a}$ The data were determined in our laboratory by thermal denaturation. The subdivisions of Pseudomonas given are the combined results of the classification in Bergey's Manual, 8th ed. (17), and of unpublished hybridization data from this laboratory. The subdivisions in the Alcaligenes - Achromobacter group are due solely to data from this laboratory (13; unpublished data).

tween 60 and $65^{\circ} \mathrm{C}$ are the Vibrionaceae, the Enterobacteriaceae, the pseudomonads of section I (17), Xanthomonas, Aplanobacter, Azotobacter, and Azomonas, the marine "Alcaligenes" ("Alc." pacificus, "Alc." venustus, "Alc." aestus, and "Alc." aquamarinus), Agarbacterium, Cellvibrio, and a few other strains. (ii) Between 57 and $61.5^{\circ} \mathrm{C}$ are the Rhizobiaceae and their relatives (Agrobacterium, Rhizobium, Mycoplana, Phyllobacterium, "Chromobacterium folium"), Gluconobacter, Acetobacter, Zymomonas, Paracoccus, and some Rhodopseudomonas. (iii) All remaining taxa investigated are below $T_{m(e)} 62^{\circ} \mathrm{C}$, in spite of the fact that some of them (e.g., Bacillus) have a high percent rRNA binding: Flavobacterium, Arthrobacter, Corynebacterium, Microcyclus, Campylobacter, Cytophaga, and HeLa.

It is well known that there is excellent correlation between the dendrogram of amino acid sequences of cytochromes $c$ from higher organisms and the phylogenetic relationship between these organisms, known from paleontological, comparative embryological, anatomical, and other data. We submit, as we did for the Rhizobiaceae (16), that a similar correlation may hold between the overall phenotypical and phylogenetic relationship of bacteria and the base sequences of their rRNA [here expressed as $\left.T_{m(e)}\right]$. 


\section{ACKNOWLEDGMENTS}

J.D.L. thanks the Fonds voor Kollektief Fundamenteel Onderzoek for personnel and research grants. We thank the many laboratories, institutes, and individuals for their donation of strains.

\section{REPRINT REQUESTS}

Address requests for reprints to: Prof. J. De Ley, Laboratory for Microbiology, RUG, K.L. Ledeganckstraat, 35, B-9000 Gent, Belgium.

\section{LITERATURE CITED}

1. Bettelheim, K. A., J. F. Gordon, and J. Taylor. 1968. The detection of a strain of Chromobacterium lividum in the tissues of certain leaf nodulated plants by the immunofluorescence technique. J. Gen. Microbiol. 54:177-184.

2. Breed, R. S. 1957. Genus III. Chromobacterium Bergonzini, 1881, p. 292-296. In R. S. Breed, E. G. D. Murray, and N. R. Smith (ed.), Bergey's manual of determinative bacteriology, 7th ed. The Williams \& Wilkins Co., Baltimore, Md.

3. Breed, R. S., E. G. D. Murray, and A. P. Hitchens (ed.). 1948. Bergey's manual of determinative bacteriology, 6th ed. The Williams \& Wilkins Co., Baltimore, Md.

4. Breed, R. S., E. G. D. Murray, and N. R. Smith (ed.) 1957. Bergey's manual of determinative bacteriology, 7 th ed. The Williams \& Wilkins Co., Baltimore, Md.

5. Buchanan, R. E., and N. E. Gibbons (ed.). 1974. Bergey's manual of determinative bacteriology, 8th ed. The Williams \& Wilkins Co., Baltimore, Md.

6. Burton, K. 1956. A study of the conditions and mechanism of the diphenylamine reaction for the colorimetric estimation of deoxyribonucleic acid. Biochem. J. 62:315-323.

7. De Ley, J. 1964. Effect of mutation on DNA-composition of some bacteria. Antonie van Leeuwenhoek J. Microbiol. Serol. 30:281-288.

8. De Ley, J. 1968. DNA base composition of yellow Erwinia strains. Antonie van Leeuwenhoek J. Microbiol. Serol. 34:257-262.

9. De Ley, J. 1968. DNA base composition and hybridization in the taxonomy of phytopathogenic bacteria. Annu. Rev. Phytopathol. 6:63-90.

10. De Ley, J. 1970. Reexamination of the association between melting point, buoyant density, and chemical base composition of deoxyribonucleic acid. J. Bacteriol. 101:738-754.

11. De Ley, J., H. Cattoir, and A. Reynaerts. 1970. The quantitative measurement of DNA hybridization from renaturation rates. Eur. J. Biochem. 12:133-142.

12. De Ley, J., and J. De Smedt. 1975. Improvements of the membrane filter method for DNA:rRNA hybridization. Antonie van Leeuwenhoek J. Microbiol. Serol. 41:287-307.

13. De Ley, J., K. Kersters, J. Khan-Matsubara, and J. M. Shewan. 1970. Comparative D-gluconate metabolism and DNA base composition in Achromobacter and Alcaligenes. Antonie van Leeuwenhoek J. Microbiol. Serol. 36:193-207.

14. De Ley, J., and R. Tytgat. 1970. Evaluation of membrane filter methods for DNA:DNA hybridization. Antonie van Leeuwenhoek J. Microbiol. Serol. 36:461-474.

15. De Ley, J., and J. Van Muylem. 1963. Some applications of deoxyribonucleic acid base composition in bacterial taxonomy. Antonie van Leeuwenhoek J. Microbiol. Serol. 29:344-358.

16. De Smedt, J., and J. De Ley. 1977. Intra- and intergeneric similarities of Agrobacterium ribosomal ribonucleic acid cistrons. Int. J. Syst. Bacteriol. 27:222-240.

17. Doudoroff, M., and N. J. Palleroni. 1974. Pseudomonas Migula 1894, 237, p. 217-243. In R. E. Buchanan and N. E. Gibbons (ed.), Bergey's manual of determinative bacteriology, 8th ed. The Williams \& Wilkins Co., Baltimore, Md.

18. Gillis, M., and J. De Ley. 1975. Determination of the molecular complexity of double-stranded phage genome DNA from initial renaturation rates. The effect of DNA base composition. J. Mol. Biol. 98:447-464.

19. Gillis, M., J. De Ley, and M. De Cleene. 1970. The determination of molecular weight of bacterial genome DNA from renaturation rates. Eur. J. Biochem. 12:143-153.

20. Heberlein, G. T., J. De Ley, and R. Tytgat. 1967. Deoxyribonucleic acid homology and taxonomy of Agrobacterium, Rhizobium, and Chromobacterium. J. Bacteriol. 94:116-124.

21. Kirby, K. S. 1957. A new method for the isolation of deoxyribonucleic acids; evidence on the nature of bonds between deoxyribonucleic acid and protein. Biochem. J. 66:495-504.

22. Kirby, K. S., E. Fox-Carter, and M. Guest. 1967. Isolation of deoxyribonucleic acid and ribosomal ribonucleic acid from bacteria. Biochem. J. 104:258-262.

23. Lapage, S. P., P. H. A. Sneath, E. F. Lessel, V. B. D. Skerman, H. P. R. Seeliger, and W. A. Clark (ed.). 1975. International code of nomenclature of bacteria. American Society for Microbiology, Washington, D.C.

24. Leifson, E. 1956. Morphological and physiological characteristics of the genus Chromobacterium. J. Bacteriol. 71:393-400.

25. Marmur, J. 1961. A procedure for the isolation of deoxyribonucleic acid from micro-organisms. J. Mol. Biol. 3:208-218.

26. Meys, W. H., and R. A. Schilperoort. 1971. Determination of the amount of DNA on nitrocellulose membrane filters. FEBS Lett. 12:166-168.

27. Moore, R. L., and B. J. McCarthy. 1967. Comparative study of ribosomal ribonucleic acid cistrons in enterobacteria and myxobacteria. J. Bacteriol. 94:1066-1074

28. Palleroni, N. J., R. Kunisawa, R. Contopoulou, and M. Doudoroff. 1973. Nucleic acid homologies in the genus Pseudomonas. Int. J. Syst. Bacteriol, 23:333-339.

29. Sneath, P. H. A. 1956. Cultural and biochemical charac teristics of the genus Chromobacterium. J. Gen. Microbiol. 15:70-98.

30. Sneath, P. H. A. 1957. The application of computers to taxonomy. J. Gen. Microbiol. 17:201-226.

31. Sneath, P. H. A. 1960. A study of the bacterial genus Chromobacterium. Iowa State J. Sci. 34:243-500.

32. Sneath, P. H. A. 1974. Chromobacterium Bergonzini 1881, 153, p. 354-357. In R. E. Buchanan and N. E. Gibbons (ed.), Bergey's manual of determinative bacteriology, 8th ed. The Williams \& Wilkins Co., Baltimore, Md.

33. Sneath, P. H. A., and V. B. D. Skerman. 1966. A new list of type and reference strains of bacteria. Int. J. Syst. Bacteriol. 16:1-133.

34. Stanier, R. Y., N. J. Palleroni, and M. Doudoroff. 1966. The aerobic pseudomonads: a taxonomic study. J. Gen. Microbiol. 43:159-271. 